Plant Production Science

http:/www.journals.zu.edu.eg/journalDisplay.aspx?Journalld=1\&queryType=Master

\title{
IMPACT OF SOWING MODELS, NITROGEN LEVELS AND BIOFERTILIZATION ON YIELDS AND QUALITY OF SUGAR BEET UNDER SANDY SOIL CONDITIONS
}

\author{
Hazem M. Sarhan* and Maha M. El-Zeny \\ Sugar Crops Res. Inst., Agric. Res. Cent., Giza, Egypt
}

Received: 24/12/2019 ; Accepted: 08/03/2020

\begin{abstract}
The aim of this research is to study the influence of sowing models (one side of ridges, $60 \mathrm{~cm}$ apart, $15 \mathrm{~cm}$ between hills and both sides of terraces, $90 \mathrm{~cm}$ apart, $20 \mathrm{~cm}$ between hills), nitrogen fertilizer levels $(70,90$ and $110 \mathrm{~kg} \mathrm{~N} / \mathrm{fad}$.) and biofertilization treatments (treate soil with Cerialin, Rhizobacterin and the mixture of Cerialin and Rhizobacterin) on yield and quality of sugar beet, Karam cultivar under sandy soil conditions. Two field experiment were carried out at Kalabsho Experimental Farm, Dakahlia Governorate, Sugar Crops Research Institute, Agricultural Research Center, Egypt, during 2014/2015 and 2015/2016 seasons. The experiments were carried out in splitsplit plot design with four replications. The main plots were assigned to sowing models. The sub-plots were occupied with nitrogen fertilizer levels. While, the sub-sub plots were allocated with biofertilization treatments. The obtained results showed that sowing sugar beet in both sides of terraces, $90 \mathrm{~cm}$ apart, at $20 \mathrm{~cm}$ between hills attained the highest values of yield components, most of root juice quality parameters and yields, followed by sowing in one side of ridges, $60 \mathrm{~cm}$ apart, at 15 $\mathrm{cm}$ between hills in both seasons. The highest value for each of yield components, most of root juice quality parameters and yields were produced from fertilizing beet plants with $110 \mathrm{~kg} \mathrm{~N} / \mathrm{fad}$ in both seasons. However, application of $90 \mathrm{~kg} \mathrm{~N} / \mathrm{fad}$., induced the highest value of sugar yield and the second best value for each of yield components, root juice quality parameters, top and root yields without significant differences between them in most cases in both growing seasons. Application the mixture of Cerialin and Rhizobacterin produced the highest value for each of yield components, most of root juice quality parameters and yields in the two seasons. It can be concluded that sowing sugar beet in both sides of terraces, $90 \mathrm{~cm}$ apart, at $20 \mathrm{~cm}$ between hills and treat soil with the mixture of Cerialin + Rhizobacterin ( $225 \mathrm{~g} /$ fad., of each) biofertilizers in addition of mineral fertilizing with $90 \mathrm{~kg} \mathrm{~N} / \mathrm{fad}$., to improve productivity and quality of sugar beet under sandy soil conditions.
\end{abstract}

Key words: Sugar beet, sowing models, ridges width, nitrogen levels, biofertilization, yields, quality, sandy soils.

\section{INTRODUCTION}

Sugar beet (Beta valgaris var. saccharifera L.) crop has an important position in Egyptian crop rotation as winter crop for sugar production not only in the fertile soils, but also in poor, saline alkaline and calcareous soils. Where, it could be economically grown in the newly reclaimed soils such as at the Northern parts of Egypt as one of the most tolerant crops to salinity and wide range of climates. The total

\footnotetext{
*Corresponding author: Tel. : +2 01002363826

E-mail address: dr.hazemsarhan2004@gmail.com
}

amount of sugar produced is not adequate enough to our consumption. So, increasing the cultivated area and sugar production per unit area is considered one of the important national targets to minimize the gap between sugar consumption and production. Sugar beet is grown under a wide range of climates and soil types. Developing high yielding cultivars and improving agricultural practices such as sowing models, nitrogen fertilizer levels and biofertilization treatments are essential to enhance sugar beet productivity and quality. 
The best sowing models of sugar beet plants grown in hills, depends on the optimum space assigned for individual plants, which decrease the intra competition among plants, enabling their foliage to receive an appropriate amount of solar radiation along with enough water and nutrients, which ensure a maximum photosynthesis rate, and consequently higher root fresh weight (El-Douby et al., 2000). Farghaly et al. (2003), El-Bakary (2006), Gadallah et al. (2006), Attia et al.(2007), Sarhan et al. (2012) as well as Abdou and Badawy (2014) mentioned that the optimum distribution of sugar beet gave the highest return per unit area and total income to the farmer. AlJbawi et al. (2016) mentioned that the distribution of $25 \mathrm{~cm}$ (hill spacing) $\times 50 \mathrm{~cm}$ (row width) resulted in the highest production traits, but to get a higher sucrose (\%), it is recommended to grow the beet roots at spacing of $30 \times 60 \mathrm{~cm}$. Malik et al. (2016) reported that the maximum sugar beet sugar yield/ha were recorded in case of planting sugar beet on $30 \mathrm{x}$ $90 \mathrm{~cm}$ spacing paired row strips. Ibrahim (2017) revealed that sowing beet plants on both sides of terraces of $100 \mathrm{~cm}$ width with $20 \mathrm{~cm}$ spacing among hills attained the highest value for each of length of root, diameter and fresh weight/plant, foliage weight/plant as well as top, root and sugar yields/fad. While, the highest value for each of sucrose and purity percentages recorded when sugar beet plants were sown on one side of ridges of $50-\mathrm{cm}$ width with hill spacing of $20 \mathrm{~cm}$. Saini and Brar (2017) concluded that planting sugar beet as two rows on beds or two rows on both side of ridge could be recommended for cultivation of sugar beet in loamy sand soils.

Nitrogen is an essential element for sugar beet growth and yield, especially in sandy soil. Application mineral nitrogen fertilizer to the plant increase the amount of protein, protoplasm and chlorophyll formed, building up metabolites and activation of enzymes that associate with accumulation of carbohydrates, which translated from leaves to increasing division and elongation of cells, accordingly increasing growth and yield of plants. In this concern, Abdou (2000), Saif (2000), Shalaby et al. (2003), Seadh (2004), Leilah et al. (2007), Shewate et al. (2008), El-Sarag (2009), Zhang et al. (2009), Jahedi and Noroozi (2010), Attia et al. (2011), Ferweez et al. (2011), Sarhan (2012), Shaban et al. (2014), Mekdad (2015) and Nemeata Alla (2016) concluded that increasing nitrogen mineral fertilizer levels up to 100 or $110 \mathrm{~kg} \mathrm{~N} /$ fad., significantly increased root length, root diameter, top yield/fad., root yield/fad., and sugar yield/fad. Whereas, TSS, sucrose and purity percentages were decreased. Moreover, Abdelaal and Tawfik (2016) and El-Hassanin et al. (2016) confirmed that increasing nitrogen fertilizer levels caused increase in total chlorophyll, leaf area, foliage length, foliage and root fresh weights, root length, root diameter, top yield/fad., root yield/ fad., and sugar yield/fad. On the other hand, Monreala et al. (2007), El-Geddawy et al. (2008) and Abdelaal and Tawfik (2016) reported that there were a decrease on both of sucrose and purity percentage due to increasing mineral nitrogen levels, this may be due to the increase in amino compounds caused by the extreme of nitrogen uptake. Chatterjee et al. (2018) suggested that revision of current sugar beet nitrogen fertilizer recommendation to replace the single rate with nitrogen rates based on site characteristics and profitability to nitrogen applications.

In recent years, biofertilizer technologies are based on enhancing and improving the naturally existing nutrient transformation activities in the soil profiles, when the inoculant should be able to be adapted to the environmental conditions prevailing in the site of application, which minimizing the environmental pollution resulting from mineral fertilizers and also to reduce its coasts (Abu El-Fotoh et al., 2000). So, biological nitrogen fixation of sugar beet with nonsymbiotic nitrogen fixers play an important role in increasing growth and yield as well as decreasing chemical nitrogen fertilizer requirements and consequently minimizing environmental pollution by mineral fertilizers and to save its costs. In this regard, Bassal et al. (2001) reported that inoculation of sugar beet seeds with Azotobacterin significantly increased TSS $(\%)$, sucrose (\%), purity (\%) and root as well as sugar yields/fad. Cakmakci et al. (2001) and Maareg and Badr (2001) revealed that Syrialin caused an increase in each of TSS (\%), sucrose (\%), purity (\%) and sugar yield/fad. Kandil et 
al. (2002) showed that inoculation seeds of sugar beet with Rhizobacterin significantly increased root, top and sugar yields/fad. Ramadan et al. (2003) found that biofertilization treatments had significant effect on root, top and sugar yields/fad. On the other hand, biofertilization treatments exhibited insignificant effect in sucrose (\%) and purity (\%). Badawi et al. (2004) found that Rhizobacterin treatment produced the highest values of quality parameters [TSS (\%), sucrose (\%), purity (\%)] and yield (root, top and sugar yields/fad.) in both seasons. Sarhan (2012) stated that application the mixture of Microbeen + Rhizobacterin + Phosphorien produced the highest values of root length and diameter, root and foliage fresh weights, TSS $(\%)$, sucrose (\%), purity (\%), root and sugar yields/fad., as compared with using each biofertilizer alone. Mahmoud et al. (2014) found that increasing nitrogen rates from 60 to 80 $\mathrm{kg} / \mathrm{fad}$., in combination with $\mathrm{N}$-fixing bacteria depressed beet quality and increased impurities in beet roots. The highest root and top yields resulted from application of $100 \mathrm{~kg} \mathrm{~N} /$ fad., while sugar yield was the highest with the combination of Azotobacter + Azospirillum besides 60 or $80 \mathrm{~kg} \mathrm{~N} /$ fad., followed by $100 \mathrm{~kg}$ $\mathrm{N} /$ fad. Zaki et al. (2018) concluded that fertilizing sugar beet plants with (ammonium sulphate) $100 \mathrm{~kg} \mathrm{~N} /$ fad., and inoculated with biofertilizer (Ntrobin $600 \mathrm{~g} / \mathrm{fad}$.) increased the growth rate sugar beet plants under sandy soil conditions.

Thus, this investigation was carried out to study the impact of sowing models, nitrogen fertilizer levels and biofertilization treatments on yields and quality of sugar beet under the environmental conditions of sandy soil in Kalabsho region, Dakahlia Governorate, Egypt.

\section{MATERIALS AND METHODS}

Two field experiments were carried out at Kalabsho Experimental Farm, Dakahlia Governorate, Sugar Crops Research Institute, Agricultural Research Center, Egypt, during 2014/2015 and 2015/2016 seasons. The main objective of this study was to determine the influence of sowing models, nitrogen fertilizer levels and biofertilization treatments on yields and quality of sugar beet, Karam cultivar under sandy soil conditions.
The experiments were carried out in splitsplit plot design with four replications. The main plots were assigned to sowing models with the same plant density of 46666 plants/fad., as follows:

1. Sowing sugar beet in one side of ridges, 60 $\mathrm{cm}$ apart, at $15 \mathrm{~cm}$ between hills.

2. Sowing sugar beet in both sides of terraces, $90 \mathrm{~cm}$ apart, at $20 \mathrm{~cm}$ between hills.

The sub-plots were occupied with nitrogen fertilizer levels (70, 90 and $110 \mathrm{~kg} \mathrm{~N} / \mathrm{fad}$ ). Nitrogen fertilizer as aforementioned levels in the forms of urea $(46.5 \% \mathrm{~N})$ was applied as a side-dressing in three equal doses, the first part was applied after thinning sugar beet plants (30 days from sowing), the second part was applied after 45 days from sowing, and the third portion was applied after 60 days from sowing.

The sub-sub plots were allocated with the following three biofertilization treatments:

1. Treated soil with Cerialin ( $450 \mathrm{~g} / \mathrm{fad}$.).

2. Treated soil with Rhizobacterin (450 g/fad.).

3. Treated soil with Cerialin + Rhizobacterin (225 g/fad., of each).

Cerialin and Rhizobacterin as commercial products were produced by Biofertilizer Unit, Agriculture Research Center (ARC), Giza, Egypt, which included free-living bacteria able to fix atmospheric nitrogen in the rhizosphere of soil. The biofertilizer treatments were done before first irrigation directly by mixing the recommended dose of each biofertilizer with fine clay as side-dress near from hills.

Each experimental basic unit included 5 ridges, each $60 \mathrm{~cm}$ apart and $4.5 \mathrm{~m}$ length, and 5 terraces, each $90 \mathrm{~cm}$ apart and $3.0 \mathrm{~m}$ length, which resulted an area of $13.5 \mathrm{~m}^{2}$ for both.

Soil samples were taken at random from the experimental field area at a depth of $0-30 \mathrm{~cm}$ from soil surface before soil preparation to measure the physical and chemical soil properties as shown in Table 1.

The experimental field well prepared through three ploughings, leveling, compaction, ridging, division and then divided into the experimental units $\left(13.5 \mathrm{~m}^{2}\right)$ as formerly describ. Calcium super phosphate $\left(15.5 \% \mathrm{P}_{2} \mathrm{O}_{5}\right)$ at $200 \mathrm{~kg} / \mathrm{fad}$., was 
Table 1. Physical and chemical properties of soil at the experimental field in 2014/2015 and 2015/2016 seasons

\begin{tabular}{|c|c|c|c|}
\hline \multicolumn{2}{|l|}{$\overline{\text { Variable }}$} & $2014 / 2015$ & $2015 / 2016$ \\
\hline \multicolumn{4}{|l|}{ A: Mechanical analysis } \\
\hline \multicolumn{2}{|l|}{ Sand $(\%)$} & 91.40 & 91.80 \\
\hline \multicolumn{2}{|l|}{ Silt (\%) } & 4.95 & 5.05 \\
\hline \multicolumn{2}{|l|}{ Clay $(\%)$} & 3.65 & 3.15 \\
\hline \multicolumn{2}{|l|}{ Soil texture } & Sandy & Sandy \\
\hline \multicolumn{4}{|l|}{ B: Chemical analysis } \\
\hline \multicolumn{2}{|l|}{ Soil reaction $\mathrm{pH}$} & 8.07 & 7.91 \\
\hline \multicolumn{2}{|c|}{$\mathrm{EC}\left(\mathrm{dS} \mathrm{m}^{-2}\right)$ in soil water extraction $(1: 5)$ at $25^{0} \mathrm{C}$} & 2.89 & 2.81 \\
\hline \multicolumn{2}{|l|}{ Organic matter (\%) } & 0.166 & 0.195 \\
\hline \multicolumn{2}{|l|}{$\mathrm{CaCO}_{3}(\%)$} & 0.78 & 0.71 \\
\hline \multirow{3}{*}{ Macronutrients (ppm) } & Total N & 18.50 & 20.50 \\
\hline & Available P & 2.85 & 2.97 \\
\hline & Available K & 78.00 & 83.00 \\
\hline \multirow{4}{*}{ Soluble cations (meq L ${ }^{-1}$ ) } & $\mathrm{Ca}^{++}$ & 1.19 & 1.12 \\
\hline & $\mathrm{Mg}^{++}$ & 0.46 & 0.53 \\
\hline & $\mathrm{Na}^{+}$ & 5.53 & 5.27 \\
\hline & $\mathrm{K}^{+}$ & 0.19 & 0.21 \\
\hline \multirow{4}{*}{ Soluble anions (meq L ${ }^{-1}$ ) } & $\mathrm{CO}_{3}^{--}$ & 0.00 & 0.00 \\
\hline & $\mathrm{HCO}_{3}^{-}$ & 1.15 & 1.11 \\
\hline & $\mathrm{SO}_{4}^{--}$ & 0.76 & 0.88 \\
\hline & $\mathrm{Cl}^{-}$ & 4.85 & 4.70 \\
\hline
\end{tabular}

applied during soil preparation. Sugar beet balls were hand sown 3-5 balls/hill using dry sowing method in the first week of November in both growing seasons. The plots were immediately irrigated after sowing. Potassium sulphate $(48 \%$ $\mathrm{K}_{2} \mathrm{O}$ ) at the rate of $24 \mathrm{~kg} / \mathrm{fad}$., was applied after 30 days from sowing. Plants were thinned at the age of 30 days from sowing to obtain one plant/ hill. Plants were kept free from weeds, which were manually controlled by hand hoeing at three times. The other recommended agricultural practices for growing sugar beet were applied by Sugar Crops Research Institute recommendations, except the factors under study.

\section{The Studied Traits}

\section{Yield components}

At harvest, five plants were chosen at random from the outer ridges or terraces of each sub-plot to determine yield components as follows:

1- Root fresh weight (kg/plant).

2- Foliage fresh weight (kg/plant).

3- Root length (cm).

4- Root diameter $(\mathrm{cm})$. 


\section{Root juice quality parameters}

All root juice quality parameters were determined in Dakahlia Sugar Company, Bilkas Sugar Factory Laboratories, Dakahlia Governorate, Egypt. The root juice quality parameters were as follows:

1- Sodium percentage (\%).

2- Potassium percentage (\%).

3- $\alpha$-amino nitrogen percentage (\%).

4- Sucrose percentage (\%).

5- Quality percentage (\%).

\section{Yields}

Plants that produced from the two inner ridges or terraces of each sub-plot at harvesting time were collected and cleaned, and then roots and tops were separated and weighted in kilograms and converted to estimate:

1- Top yield (ton/fad.).

2- Root yield (ton/fad.).

3- Sugar yield (ton/fad.).

It was calculated by multiplying root yield by sucrose percentage.

The obtained data were statistically analyzed according to the technique of analysis of variance (ANOVA) for the split-split plot design as published by Gomez and Gomez (1984) using computer software package "MSTAT-C". Least significant difference (LSD) method was used to compare the differences among treatment means at 5\% level of probability as described by Snedecor and Cochran (1980).

\section{RESULTS AND DISCUSSION}

\section{Effect of Sowing Models}

Results presented in Tables 2, 3 and 4 show that sowing models of sugar beet i.e. one side of ridges, $60 \mathrm{~cm}$ apart, at $15 \mathrm{~cm}$ between hills and both sides of terraces, $90 \mathrm{~cm}$ apart, at $20 \mathrm{~cm}$ between hills exhibited significant effect on root diameter, sodium $(\mathrm{Na}), \alpha$-amino-nitrogen, sucrose and quality percentages in both studied seasons and sugar yield in the second season. While, the differences in root and foliage fresh weights/plant, root length, potassium (K) percentages, top and root yields/fad., in both seasons and sugar yield in the first season did not reached the level of significance as a result of studied sowing models of sugar beet.

Sowing sugar beet in both sides of terraces, $90 \mathrm{~cm}$ apart, at $20 \mathrm{~cm}$ between hills attained the highest value for each of root and foliage fresh weights/plant, root length and diameter, sucrose and purity percentages in root juice, top, root and sugar yields/fad., in both seasons. The second best sowing model in both seasons was sowing sugar beet in one side of ridges, $60 \mathrm{~cm}$ apart, at $15 \mathrm{~cm}$ between hills with little and insignificant differences in most of previously mentioned characters. The increment in yield components, some of root juice quality parameters and yields of sugar beet associated with sowing in both sides of terraces, $90 \mathrm{~cm}$ apart, at $20 \mathrm{~cm}$ between hills may be due to that sowing model ensured better conditions concerning foliage light interception and decreased the intra-specific competition between sugar beet plants for growth factors, which positively contributed to higher photosynthesis rate and hence higher values of fresh weight of plant, root length and diameter, which participated in increasing root, top and sugar yields/fad. These results are in harmony with those reported by Sarhan et al. (2012), Abdou and Badawy (2014), Al-Jbawi et al. (2016), Malik et al. (2016) and Ibrahim (2017).

Sodium $(\mathrm{Na})$, potassium $(\mathrm{K})$ and $\alpha$-aminonitrogen percentages in sugar beet root juice recorded the highest values in both seasons, when sugar beet sown in one side of ridges, 60 $\mathrm{cm}$ apart, at $15 \mathrm{~cm}$ between hills compared with sown in both sides of terraces, $90 \mathrm{~cm}$ apart, at 20 $\mathrm{cm}$ between hills without significant differences between them in $\mathrm{K}$ percentages. These results may be due to the decrease in root weight and diameter, low tissue water content and hence increasing $\mathrm{Na}, \mathrm{K}$ and $\alpha$-amino- $\mathrm{N}$ determined as per cents in the fresh samples. El-Bakary (2006), Gadallah et al. (2006), Attia et al. (2007) and Sarhan et al. (2012) confirmed these results.

\section{Effect of nitrogen fertilizer levels}

All yield components of sugar beet (root and foliage fresh weights/plant, root length and diameter) were significantly increased as a result 
Table 2. Root and foliage fresh weights/plant, root length and diameter of sugar beet as affected by sowing models, nitrogen fertilizer levels and biofertilization treatment as well as their interactions during 2014/2015 and 2015/2016 seasons

\begin{tabular}{|c|c|c|c|c|c|c|c|c|}
\hline \multirow{2}{*}{$\begin{array}{c}\text { Main effect and interaction } \\
\text { Season }\end{array}$} & \multicolumn{2}{|c|}{$\begin{array}{l}\text { Root fresh } \\
\text { weight } \\
\text { (g/plant) }\end{array}$} & \multicolumn{2}{|c|}{$\begin{array}{c}\text { Foliage fresh } \\
\text { weight (g/plant) }\end{array}$} & \multicolumn{2}{|c|}{$\begin{array}{l}\text { Root length } \\
\text { (cm) }\end{array}$} & \multicolumn{2}{|c|}{$\begin{array}{l}\text { Root diameter } \\
\text { (cm) }\end{array}$} \\
\hline & $\begin{array}{l}2014 / \\
2015\end{array}$ & $\begin{array}{l}2015 / \\
2016\end{array}$ & $\begin{array}{l}2014 / \\
2015\end{array}$ & $\begin{array}{l}2015 / \\
2016\end{array}$ & $\begin{array}{l}2014 / \\
2015\end{array}$ & $\begin{array}{l}2015 / \\
2016\end{array}$ & $\begin{array}{l}2014 / \\
2015\end{array}$ & $\begin{array}{l}2015 / \\
2016\end{array}$ \\
\hline \multicolumn{9}{|l|}{ A- Sowing models } \\
\hline Ridges & 977.0 & 909.3 & 299.3 & 275.4 & 29.20 & 29.95 & 12.88 & 13.06 \\
\hline Terraces & 977.6 & 970.9 & 302.9 & 276.2 & 30.18 & 30.82 & 13.07 & 13.21 \\
\hline F. test & NS & NS & NS & NS & NS & NS & $*$ & $*$ \\
\hline \multicolumn{9}{|l|}{ B- Nitrogen fertilizer levels } \\
\hline $70 \mathrm{~kg} \mathrm{~N} / \mathrm{fad}$. & 905.7 & 801.3 & 280.7 & 252.2 & 27.17 & 27.92 & 11.49 & 11.64 \\
\hline $90 \mathrm{~kg} \mathrm{~N} / \mathrm{fad}$. & 993.7 & 987.6 & 308.1 & 282.4 & 30.94 & 31.59 & 13.35 & 13.52 \\
\hline $110 \mathrm{~kg} \mathrm{~N} /$ fad. & 1032.5 & 1031.4 & 314.5 & 292.7 & 30.95 & 31.64 & 14.09 & 14.24 \\
\hline LSD at $5 \%$ & 62.7 & 71.6 & 17.7 & 17.3 & 0.90 & 0.93 & 0.11 & 0.15 \\
\hline \multicolumn{9}{|l|}{ C- Biofertilization treatments } \\
\hline Cerialin & 834.8 & 778.3 & 253.2 & 230.8 & 28.69 & 29.43 & 11.67 & 11.81 \\
\hline Rhizobacterin & 981.9 & 980.9 & 304.3 & 277.1 & 29.65 & 30.35 & 12.72 & 12.88 \\
\hline Cerialin + Rhizobacterin & 1115.2 & 1061.1 & 345.8 & 319.5 & 30.72 & 31.37 & 14.54 & 14.71 \\
\hline LSD at $5 \%$ & 52.0 & 57.4 & 18.0 & 17.5 & 0.62 & 0.65 & 0.07 & 0.10 \\
\hline \multicolumn{9}{|l|}{ D- Interactions } \\
\hline $\mathrm{A} \times \mathrm{B}$ & NS & $*$ & NS & NS & NS & NS & $*$ & $*$ \\
\hline $\mathrm{A} \times \mathrm{C}$ & NS & NS & NS & NS & NS & NS & * & $*$ \\
\hline $\mathrm{B} \times \mathrm{C}$ & $*$ & $*$ & $*$ & $*$ & $*$ & $*$ & $*$ & $*$ \\
\hline $\mathrm{A} \times \mathrm{B} \times \mathrm{C}$ & NS & NS & NS & NS & NS & * & * & $*$ \\
\hline
\end{tabular}

Where: * and NS refers to significant at 5\% level and not significant, respectively. 
Zagazig J. Agric. Res., Vol. 47 No. (2) 2020

Table 3. Sodium (Na), potassium (K), $\alpha$-amino-nitrogen, sucrose and quality percentages in sugar beet root juice as affected by sowing models, nitrogen fertilizer levels and biofertilization treatment as well as their interactions during 2014/2015 and 2015/2016 seasons

\begin{tabular}{|c|c|c|c|c|c|}
\hline Main effect and interaction & $\begin{array}{l}\mathrm{Na} \\
(\%)\end{array}$ & $\begin{array}{l}\mathrm{K} \\
(\%)\end{array}$ & $\begin{array}{c}\alpha \text {-amino-N } \\
(\%)\end{array}$ & $\begin{array}{c}\text { Sucrose } \\
(\%)\end{array}$ & $\begin{array}{c}\text { Quality } \\
\text { (\%) }\end{array}$ \\
\hline & $\begin{array}{cc}2014 / & 2015 / \\
2015 & 2016 \\
\end{array}$ & $\begin{array}{cc}2014 / 2015 / \\
2015 & 2016 \\
\end{array}$ & $\begin{array}{cc}2014 / & 2015 / \\
2015 & 2016 \\
\end{array}$ & $\begin{array}{cc}2014 / 2015 / \\
2015 & 2016 \\
\end{array}$ & $\begin{array}{cc}2014 / 2015 / \\
2015 & 2016\end{array}$ \\
\hline
\end{tabular}

A- Sowing models

$\begin{array}{lcccccccccc}\text { Ridges } & 1.70 & 1.63 & 4.96 & 4.74 & 3.85 & 3.28 & 19.80 & 19.33 & 80.93 & 80.98 \\ \text { Terraces } & 1.64 & 1.55 & 4.73 & 4.62 & 3.55 & 2.99 & 20.59 & 20.11 & 85.46 & 84.80 \\ \text { F. test } & * & * & \text { NS } & \text { NS } & * & * & * & * & * & *\end{array}$

B- Nitrogen fertilizer levels

$\begin{array}{lcccccccccc}70 \mathrm{~kg} \mathrm{~N} / \text { fad. } & 1.52 & 1.47 & 4.20 & 4.18 & 3.28 & 2.72 & 21.15 & 20.65 & 91.90 & 91.92 \\ 90 \mathrm{~kg} \mathrm{~N} / \text { fad. } & 1.56 & 1.47 & 4.39 & 4.10 & 3.42 & 2.86 & 20.62 & 20.16 & 86.11 & 86.31 \\ 110 \mathrm{~kg} \mathrm{~N} / \text { fad. } & 1.92 & 1.82 & 5.95 & 5.77 & 4.40 & 3.82 & 18.82 & 18.35 & 71.58 & 70.43 \\ \text { LSD at 5\% } & 0.04 & 0.08 & 0.23 & 0.25 & 0.11 & 0.12 & 0.19 & 0.20 & 1.91 & 1.75 \\ \text { C- Biofertilization treatments } & & & & & & & & & \\ \text { Cerialin } & 1.81 & 1.73 & 5.73 & 5.43 & 3.89 & 3.31 & 19.57 & 19.10 & 82.88 & 82.29 \\ \text { Rhizobacterin } & 1.67 & 1.60 & 4.82 & 4.78 & 3.68 & 3.12 & 20.34 & 19.87 & 82.95 & 83.10 \\ \text { Cerialin + Rhizobacterin } & 1.52 & 1.43 & 3.98 & 3.84 & 3.53 & 2.97 & 20.67 & 20.18 & 83.76 & 83.27 \\ \text { LSD at 5\% } & 0.03 & 0.05 & 0.17 & 0.26 & 0.09 & 0.10 & 0.22 & 0.23 & \text { NS } & \text { NS }\end{array}$

D- Interactions

\begin{tabular}{lcccccccccc}
$\mathrm{A} \times \mathrm{B}$ & $*$ & $*$ & $\mathrm{NS}$ & $\mathrm{NS}$ & $*$ & $*$ & $*$ & $*$ & $\mathrm{NS}$ & $\mathrm{NS}$ \\
$\mathrm{A} \times \mathrm{C}$ & $*$ & $\mathrm{NS}$ & $\mathrm{NS}$ & $*$ & $*$ & $*$ & $\mathrm{NS}$ & $\mathrm{NS}$ & $\mathrm{NS}$ & $\mathrm{NS}$ \\
$\mathrm{B} \times \mathrm{C}$ & $*$ & $*$ & $*$ & $\mathrm{NS}$ & $*$ & $*$ & $*$ & $*$ & $\mathrm{NS}$ & $\mathrm{NS}$ \\
$\mathrm{A} \times \mathrm{B} \times \mathrm{C}$ & $\mathrm{NS}$ & $\mathrm{NS}$ & $\mathrm{NS}$ & $\mathrm{NS}$ & $*$ & $*$ & $\mathrm{NS}$ & $\mathrm{NS}$ & $\mathrm{NS}$ & $\mathrm{NS}$ \\
\hline
\end{tabular}

Where: * and NS refers to significant at $5 \%$ level and not significant, respectively. 
Table 4. Top, root and sugar yields/fad., of sugar beet as affected by sowing models, nitrogen fertilizer levels and biofertilization treatment as well as their interactions during 2014/ 2015 and 2015/2016 seasons

\begin{tabular}{clccccc}
\hline Main effect and interaction & \multicolumn{2}{c}{$\begin{array}{c}\text { Top yield } \\
\text { (ton/fad.) }\end{array}$} & $\begin{array}{c}\text { Root yield } \\
\text { (ton/fad.) }\end{array}$ & $\begin{array}{c}\text { Sugar yield } \\
\text { (ton/fad.) }\end{array}$ \\
\hline Season & $2014 /$ & $2015 /$ & $2014 /$ & $2015 /$ & $2014 /$ & $2015 /$ \\
& 2015 & 2016 & 2015 & 2016 & 2015 & 2016 \\
\hline
\end{tabular}

\section{A- Sowing models}

$\begin{array}{lllllll}\text { Ridges } & 6.011 & 5.557 & 19.496 & 19.421 & 3.856 & 3.777 \\ \text { Terraces } & 6.033 & 5.582 & 19.515 & 19.625 & 4.024 & 3.896\end{array}$

F. test

NS NS NS NS NS

B- Nitrogen fertilizer levels

\begin{tabular}{|c|c|c|c|c|c|c|}
\hline $70 \mathrm{~kg} \mathrm{~N} / \mathrm{fad}$. & 5.567 & 5.097 & 18.072 & 17.985 & 3.831 & 3.708 \\
\hline 90 kg N/fad. & 6.111 & 5.648 & 19.833 & 19.954 & 4.106 & 4.023 \\
\hline $110 \mathrm{~kg} \mathrm{~N} / \mathrm{fad}$ & 6.389 & 5.964 & 20.611 & 20.629 & 3.883 & 3.778 \\
\hline LSD at $5 \%$ & 0.435 & 0.424 & 1.070 & 1.015 & 0.250 & 0.219 \\
\hline \multicolumn{7}{|c|}{ C- Biofertilization treatments } \\
\hline Cerialin & 5.161 & 4.715 & 16.650 & 16.765 & 3.261 & 3.194 \\
\hline Rhizobacterin & 6.039 & 5.594 & 19.589 & 19.622 & 3.978 & 3.877 \\
\hline Cerialin + Rhizobacterin & 6.867 & 6.400 & 22.278 & 22.182 & 4.579 & 4.438 \\
\hline LSD at $5 \%$ & 0.315 & 0.409 & 1.019 & 1.026 & 0.227 & 0.224 \\
\hline
\end{tabular}

D- Interactions

$\begin{array}{ccccccc}\mathrm{A} \times \mathrm{B} & \mathrm{NS} & \mathrm{NS} & \mathrm{NS} & \mathrm{NS} & \mathrm{NS} & \mathrm{NS} \\ \mathrm{A} \times \mathrm{C} & \mathrm{NS} & \mathrm{NS} & \mathrm{NS} & \mathrm{NS} & \mathrm{NS} & \mathrm{NS} \\ \mathrm{B} \times \mathrm{C} & * & * & * & * & * & * \\ \mathrm{~A} \times \mathrm{B} \times \mathrm{C} & \mathrm{NS} & \mathrm{NS} & \mathrm{NS} & \mathrm{NS} & \mathrm{NS} & \mathrm{NS}\end{array}$

Where: * and NS refers to significant at $5 \%$ level and not significant, respectively. 
of increasing nitrogen fertilizer levels from 70 to 90 and $110 \mathrm{~kg} \mathrm{~N} /$ fad., in both seasons (Table 2). Fertilizing sugar beet plants with $110 \mathrm{~kg} \mathrm{~N} /$ fad., produced the highest values of all studied yield components in the two growing seasons. Application of $90 \mathrm{~kg} \mathrm{~N} / \mathrm{fad}$., resulted in the best findings after the highest level of nitrogen fertilizer with significant differences comparison with other levels. While, the lowest ones were obtained due to sugar beet plants fertilized with the lowest level of nitrogen fertilizer $(70 \mathrm{~kg}$ $\mathrm{N} / \mathrm{fad}$ ) in both seasons. Such effect of nitrogen on these characteristics may be returned to its role in building up metabolites and activation of enzymes that associate with accumulation of carbohydrates, which translated from leaves to developing roots as well as increasing division and elongation of cells, consequently increasing root size. The present results are in line with those obtained by Sarhan (2012), Shaban et al. (2014), Mekdad (2015) and Nemeata Alla (2016).

Significant differences in all root juice quality parameters i.e. sodium $(\mathrm{Na})$, potassium (K), $\alpha$-amino-nitrogen, sucrose and quality percentages were noticed due nitrogen fertilizer levels in both growing seasons (Table 3). The highest value for each of $\mathrm{Na}, \mathrm{K}$ and $\alpha$-aminonitrogen percentages were obtained by fertilizing sugar beet plants with the highest level of nitrogen fertilizer $(110 \mathrm{~kg} \mathrm{~N} / \mathrm{fad}$.) in both seasons. However, the highest mean for each of sucrose $(\%)$ and purity $(\%)$ were resulted from fertilizing sugar beet plants with the lowest level of nitrogen fertilizer ( $70 \mathrm{~kg} \mathrm{~N} / \mathrm{fad}$.) in the two growing seasons. The decrease in quality parameters due to excessive nitrogen application can be ascribed to its role in increasing root weight and diameter, tissue water content as well as increasing non-sucrose substances such as proteins and alpha amino acid, and hence decreasing sucrose content in roots and purity percentage. Monreala et al. (2007), ElGeddawy et al. (2008) and Abdelaal and Tawfik (2016) confirming this conclusion.

Nitrogen fertilizer levels caused significant effect on all yield characters (top, root and sugar yields/fad.) in the two growing seasons (Table 4). The highest values of top (6.389 and $5.964 \mathrm{t} /$ fad.) and root yield (20.611 and 20.629 ton/fad.) were produced from fertilizing beet plants with $110 \mathrm{~kg} \mathrm{~N} / \mathrm{fad}$., in the first and second seasons, respectively. However, application of $90 \mathrm{~kg}$ $\mathrm{N} /$ fad., induced the highest values of sugar yield (4.106 and 4.023 ton/fad.) and the second best values of top and root yields/fad., after fertilizing with $110 \mathrm{~kg} \quad \mathrm{~N} / \mathrm{fad}$., without significant differences between them in the first and second seasons, respectively. The lowest values of top (5.567 and 5.097 ton/fad.), root (18.072 and $17.985 \mathrm{ton} / \mathrm{fad}$.) and sugar yields (3.831 and 3.708 ton/fad.) were obtained from fertilizing sugar beet plants with the lowest level of nitrogen fertilizer $(70 \mathrm{~kg} \mathrm{~N} / \mathrm{fad}$.) in the first and second seasons, respectively. The increase in yield characters due to application of nitrogen fertilization can be explained through the fact that nitrogen has a vital role in building up metabolites, activating enzymes and enhanced root length, diameter as well as root fresh weight and finally root and sugar yields per unit area. Abdelaal and Tawfik (2016) and El-Hassanin et al. (2016) recorded similar tendency.

\section{Effect of biofertilization treatments}

Biofertilization treatments i.e. treated soil with Cerialin (450 g/fad.), Rhizobacterin (450 $\mathrm{g} /$ fad.) and Cerialin+ Rhizobacterin (225 g/fad., of each them) caused a significant effect on yield components as shown in Table 2. Application the mixture of Cerialin + Rhizobacterin (225 $\mathrm{g}$ /fad., of each them) produced the highest values of yield components (root and foliage fresh weights/plant, root length and diameter) in both growing seasons. It was followed by application Rhizobacterin (450 g/fad.), then application Cerialin $(450 \mathrm{~g} / \mathrm{fad}$.) with regard its effect on yield components in the two growing seasons. From obtained results under the environmental conditions of this research, it could be observed that using of Rhizobacterin biofertilizer either alone or in the mixture with Cerialin surpassed other treatment during both seasons. This increase in yield components as a result of application biofertilizers particularly Rhizobacterin may be due to its role in nitrogen fixation via free living bacteria which reduce the soil $\mathrm{pH}$ especially in the rhizosphere which led to increase the availability of most essential macro and micro-nutrients as well as excretion some growth substances such as IAA and GA3 which play an important role in formation a large and active root system and therefore increasing nutrient uptake, which stimulating establishment 
and vegetative growth, hence increasing root and foliage fresh weights and also root length and diameter. Many investigators confirming this conclusion i.e. Sarhan (2012), Mahmoud et al. (2014) and Zaki et al. (2018).

Results in Table 3 clear that application of biofertilization treatments were associated with significant effect on root juice quality parameters in the two growing seasons. Application the mixture of Cerialin+ Rhizobacterin (225 g/fad., of each) significantly improved quality traits of sugar beet and induced the highest values of sucrose and quality percentages and the lowest values of sodium $(\mathrm{Na})$, potassium $(\mathrm{K})$ and $\alpha$ amino-nitrogen percentages in the two growing seasons. Generally, it can be observed that biofertilization treatments especially that included Rhizobacterin biofertilizer led to gradual tendency to improve all quality determinations as compared with other treatment in both seasons. This increase in quality determinations due to biofertilization treatments especially Rhizobacterin may be due to its role in improving growth and dry matter accumulation by increasing the uptake and availability of most nutrients, consequently enhancement sucrose content in roots. Comparable results were reported by many workers i.e. Bassal et al. (2001), Cakmakci et al. (2001), Maareg and Badr (2001), Badawi et al. (2004) and Sarhan (2012).

Results in Table 4 show that top, root and sugar yields/fad., were significantly responded due to biofertilization treatments in both seasons. Noteworthy, application the mixture of Cerialin + Rhizobacterin (225 g/fad., of each) biofertilizers yielded the highest value for each of top (6.867 and 6.400 ton/fad.), root (22.278 and 22.182 ton/fad.) and sugar yields (4.579 and 4.438 ton/fad.) in the first and second seasons, respectively. Concerning application of Rhizobacterin (450 g/fad.), its ranked after aforementioned treatment, respectively with respecting their effect on top, root and sugar yields/fad in the two seasons. On the other hand, application of Cerialin (450 g/fad.) resulted in the lowest means of these yield traits. This effect of biofertilization treatments expressly Rhizobacterin biofertilizer may be ascribed to its role in improving plant growth, vigor of plant and yields through fixing atmospheric nitrogen and mineralization and/or mineralizing organic compounds as well as release of certain growth regulators, stimulatory compounds and nutrients in soil by the introduced organisms. Related results were in coincidence with those fixed by Kandil et al. (2002), Ramadan et al. (2003), Badawi et al. (2004), Sarhan (2012) and Mahmoud et al. (2014).

\section{Effect of interactions}

There are many significant interaction effects among sowing models, nitrogen fertilizer levels and biofertilization treatment on most of studied characters in both seasons as shown in Tables 2, 3 and 4 . We present only the significant interactions among the studied factors on yields in both seasons.

The interaction between nitrogen fertilizer levels and biofertilization treatment had a significant influence on top yield/fad., of sugar beet in both seasons as shown from results in Table 4. The recommended treatment that produced the highest values of top yield/fad., of sugar beet in both seasons was mineral fertilizing beet plants with $110 \mathrm{~kg} \mathrm{~N} /$ fad., and application the mixture of Cerialin+ Rhizobacterin (225 g/fad., of each) biofertilizers as graphically illustrated in Fig. 1. This treatment followed by mineral fertilizing with $90 \mathrm{~kg} \mathrm{~N} /$ fad., and application the mixture of Cerialin + Rhizobacterin biofertilizers in both seasons.

Root yield/fad., was significantly affected by the interaction between nitrogen fertilizer levels and biofertilization treatment during 2014/2015 and 2015/2016 seasons (Table 4). Mineral fertilizing sugar beet plants with $110 \mathrm{~kg} \mathrm{~N} / \mathrm{fad}$., and application the mixture of Cerialin + Rhizobacterin ( $225 \mathrm{~g} / \mathrm{fad}$., of each) biofertilizers produced the highest values of root yield/fad., in both seasons as graphically illustrated in Fig. 2. The second best interaction treatment was mineral fertilizing with $90 \mathrm{~kg} \mathrm{~N} /$ fad., and application the mixture of Cerialin + Rhizobacterin biofertilizers in both seasons.

Results in Table 4 reveal that sugar yield/ fad., of sugar beet was significantly influenced by the interaction between nitrogen fertilizer levels and biofertilization treatment in both seasons. The highest values of sugar yield/fad of sugar beet in both seasons were produced from mineral fertilizing with $90 \mathrm{~kg} \mathrm{~N} /$ fad., and application the mixture of Cerialin + Rhizobacterin biofertilizers as graphically illustrated in Fig. 3. 


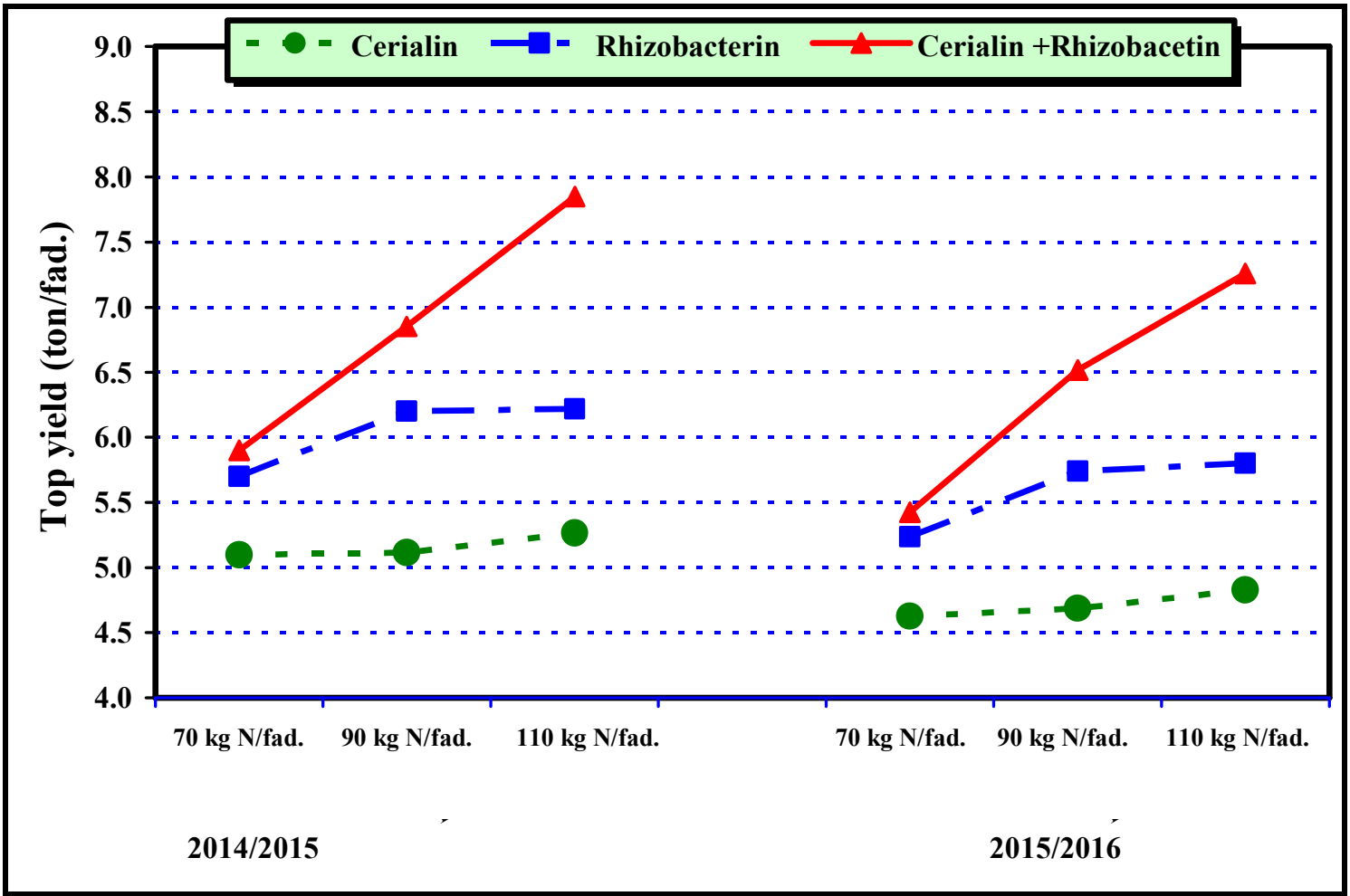

Fig. 1. Top yield/fad., of sugar beet as affected by the interaction between nitrogen fertilizer levels and biofertilization treatment during 2014/2015 and 2015/2016 seasons

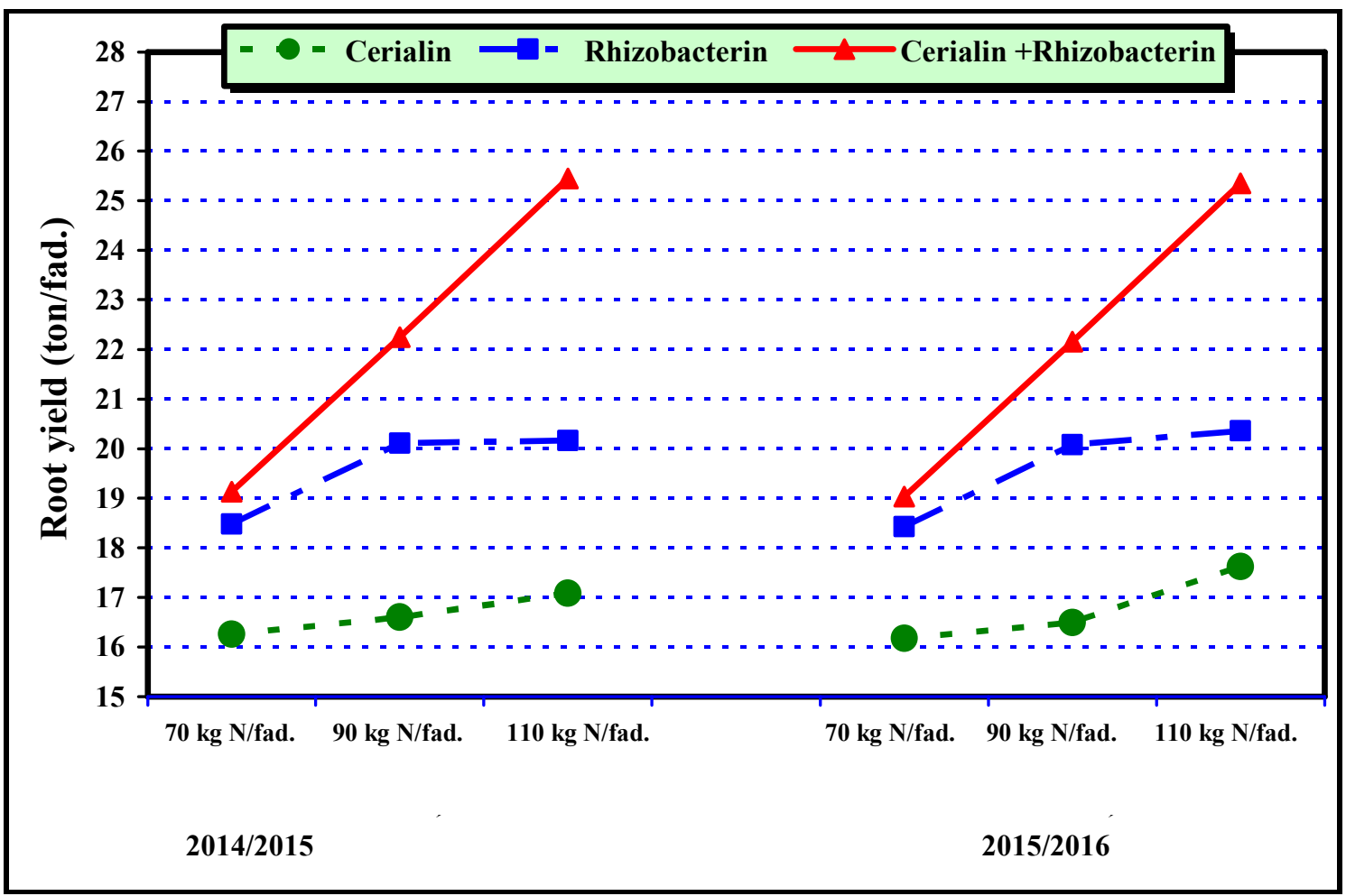

Fig. 2. Root yield/fad., of sugar beet as affected by the interaction between nitrogen fertilizer levels and biofertilization treatment during 2014/2015 and 2015/2016 seasons 


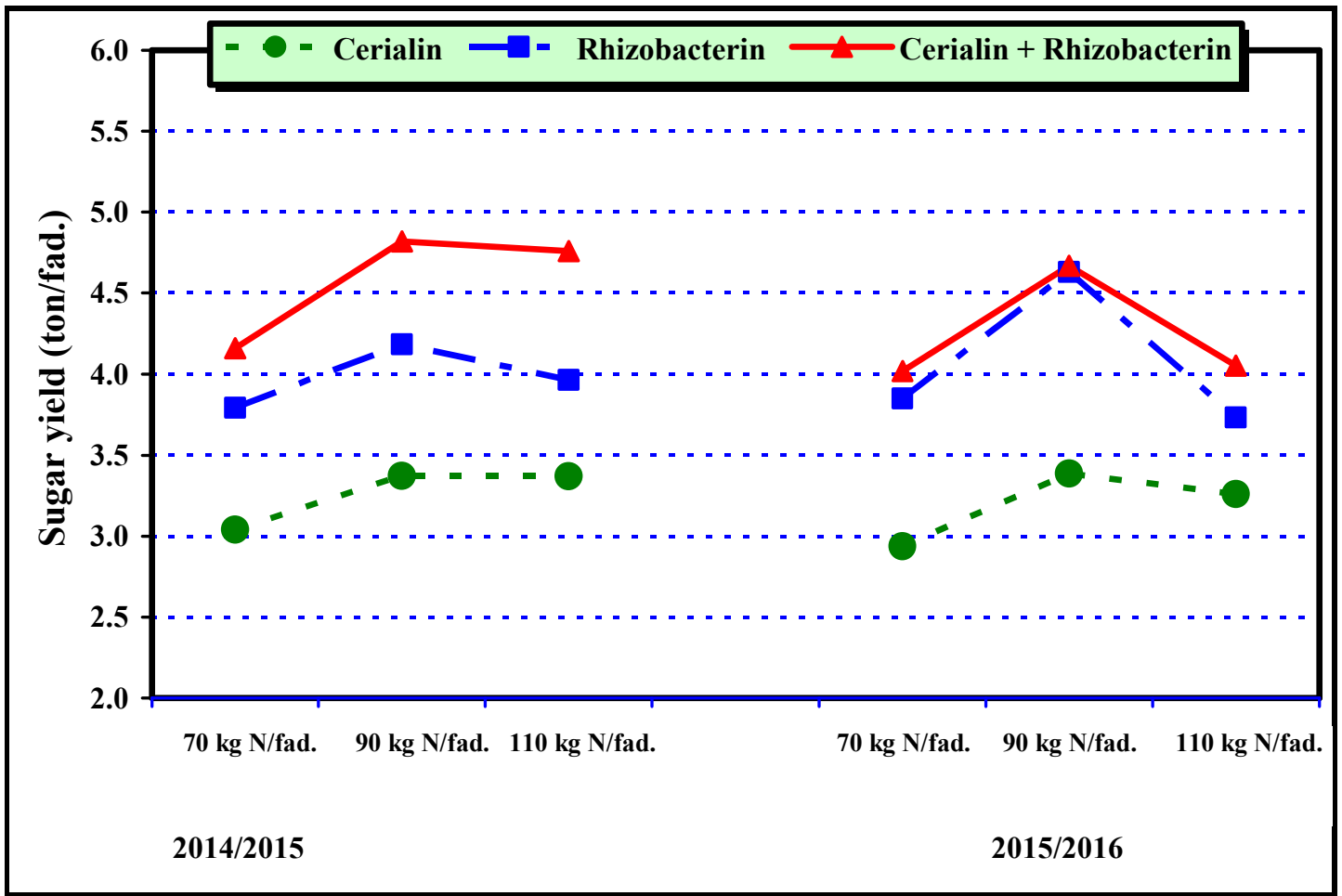

Fig. 3. Sugar yield/fad., of sugar beet as affected by the interaction between nitrogen fertilizer levels and biofertilization treatment during 2014/2015 and 2015/2016 seasons

\section{Conclusion}

Sowing sugar beet in both sides of terraces, $90 \mathrm{~cm}$ apart, at $20 \mathrm{~cm}$ between hills and treate soil with the mixture of Cerialin + Rhizobacterin (225 g/fad., of each) biofertilizers besides mineral fertilizing with $90 \mathrm{~kg} \mathrm{~N} /$ fad., is recommended to improve productivity and quality under sandy soil conditions in Dakahlia Governorate, Egypt.

\section{REFERENCES}

Abdelaal, K.A.A. and S.F. Tawfik (2016). Response of sugar beet plant (Beta vulgaris L.) to mineral nitrogen fertilization and biofertilizers. Int. J. Curr. Microbiol. App. Sci., 4 (9): 677-688.

Abdou, M.A. (2000). Effect of planting dates, plant population and nitrogen fertilization on sugar beet productivity under newly reclaimed sandy soil. Ph.D. Thesis, Fac. Agric., Kafr El-Sheikh, Tanta Univ.

Abdou, M.A. and S.A. Badawy (2014). Sugar beet productivity and quality as affected by plant density. Egypt. J. Appl. Sci., 12 (4): 148- 161.

Abu El-Fotoh, H.G., A.A. Abd El-Magid and R.E. Knany (2000). Effect of biofertilization on sugar beet yield, quality and optimization of the chemical fertilizers. Proc. $9^{\text {th }}$ Conf. Agron., 1-2 Sept. 2000, Minufiya Univ., II: 561-567.

Al-Jbawi, E., S. Al-Geddawi, G. Alesha and H. Al-Zubi (2016). Productivity of fodder beet (Beta vulgaris var. Crassa) cultivars as affected by plants spacing in Al Ghab, Syria. J. Agric. Crop Res., 4(6): 91-99.

Attia, A.N., E.M. Said, S.E. Seadh, S.S. ElMaghraby and M.E.M. Ibrahim (2011). Effect of sowing methods and weed control treatments on growth of sugar beet and weed characters under nitrogen fertilizer levels. J. Plant Prod., Mansoura Univ., 2 (6): 773-785.

Attia, A.N.E., E.M. Said, M.H. Ghonima and M.E.M. Ibrahim (2007). Impact of nitrogen levels on growth and yield of sugar beet intercropped with faba bean and wheat. J. Agric. Sci. Mansour Univ., 32 (2): 779-792. 
Badawi, M.A., A.A. Kandil, M.S. Sultan, A.N. Attia and S.E. Seadh (2004). Effect of planting dates, biofertilization and $\mathrm{NK}$ combination levels on: II- Yield and quality of sugar beet. The $4^{\text {th }}$ Sci. Conf. Agric. Sci., 7-9 Dec. 2004, Fac. Agric. Assiut Univ., 747- 762 .

Bassal, S.A.A., A.A. Zohry and K.A. Douby (2001). Effect of row and hill spacings and bio-mineral $\mathrm{N}$-fertilization rates on sugar beet productivity. J. Agric. Sci. Mansoura Univ., 26 (9): 5217-5226.

Cakmakci, R., F. Kantar and F. Sahin (2001). Effect of $\mathrm{N}_{2}$-fixing bacterial inoculation on yield of sugar beet and barley. J. Plant Nutr. and Soil Sci., 164 (5): 527-531.

Chatterjee, A., K. Subedia, D.W. Franzena, H. Mickelsonb and N. Cattanach (2018). Nitrogen fertilizer optimization for sugar beet in the red river valley of North Dakota and Minnesota. Agron. J., 110: 1554-1560.

El-Bakary, H.M.Y. (2006). Studies on yield and quality parameters of some sugar beet varieties. M.Sc. Thesis, Fac. Agric., AlAzhar Univ., Egypt.

El-Douby, K.A., S.E. Toaima and R.A. Atalla (2000). Effect of ridge width and plant distribution pattern on faba bean yield and some of its components. Ann. Agric. Sci. Moshtoher, 34 (3): 907-918.

El-Geddawy, I.H., M.S. El-Keraedy, A.M. Omar and A.E. Elmoghazy (2008). Growth and chemical constituents of sugar beet as affected by nitrogen sources and rates and boron fertilizer. Meeting on the Challenges of Sugar Crops and Integrated Industries in Dev. Countries. Al Arish, Egypt, 75-82.

El-Hassanin, A.S., M.R. Samak, M.N. Shafika, A.M. Khalifa and I.M. Ibrahim (2016). Effect of foliar application with humic acid substances under nitrogen fertilization levels on quality and yields of sugar beet plant. Int. J. Curr. Microbiol. App. Sci., 5(11): 668-680.

El-Sarag, E.I. (2009). Maximizing sugar beet yield, quality and water use efficiency using some agricultural practices in North Sinai conditions. Bull. Fac. Agric., Cairo Univ., 60: $155-167$.
Farghaly, B.S., A.A. Zohry and S.A.A. Bassal (2003). Crops management for intercropping sugar beet with some essential crops to maximize area unit productivity. Agric. Sci., Mansoura Univ., 28 (7): 5183-5199.

Ferweez, H., M.F.M. Ibrahim and A.M. Allan (2011). Improving yield and quality of sugar beet using boron at different levels of nitrogen fertilizer. Alex. Sci., Exch., 32 (1): 51-57.

Gadallah, R.E., A.M. Abdel-Galil and F.R. Nawar (2006). Maximizing productivity by intercropping some winter crops on sugar beet. J. Agric. Sci. Mansoura Univ., 31 (5): 2601-2614.

Gomez, K.N. and A.A. Gomez (1984). Statistical Procedures for Agricultural Research. $2^{\text {nd }}$ Ed., John Wiley and Sons, Inc., New York, 95-109.

Ibrahim, M.E.M. (2017). Plant distribution patterns and irrigation intervals effects on yield and quality of sugar beet in north delta. J. Plant Prod., Mansoura Univ., 8 (6): 679684.

Jahedi, A. and A. Noroozi (2010). Response of weeds to irrigation systems and amounts of nitrogen fertilizer in sugar beet. Proc. of $3^{\text {rd }}$ Iranian Seed Sci. Cong., Babolsar, Iran, 2: 111-114.

Kandil, A.A., M.A. Badawi, S.A. El-Moursy and U.M.A. Abdou (2002). Effect of planting dates, nitrogen levels and biofertilization treatments on: II- Yield, yield components and quality of sugar beet (Beta vulgaris, L.). J. Agric. Sci. Mansoura Univ., 27 (11): $7257-$ 7266.

Leilah, A.A., S. E. El-Kalla, A.T. El-Kassaby, M.A. Badawi and M.M. Fahmi (2007). Yield and quality of sugar beet in response to levels and times of nitrogen application and foliar spraying of urea. Sci. J. King Faisal Univ. (Basic and Appl. Sci.), 8 (1): 87-100.

Maareg, M.E. and S.T. Badr (2001). Impact of three soil biofertilizers applied separately and in combinations with a nematicided on Meloidogyne incognita infecting sugar beet. Egypt. J. Agronematol., 4 (1-2): 1-9. 
Mahmoud, E.A., B.S.H. Ramadan, I.H. ElGeddawy and S.F. Korany (2014). Effect of mineral and bio-fertilization on productivity of sugar beet. J. Plant Prod., Mansoura Univ., 5 (4): 699-710.

Malik, S.U., E.A. Khan and I. Hussain (2016). Morphological response of row spacing on sugar beet (Beta vulgaris) with sugarcane (Saccharum officinarum L.) intercropping. Gomal Univ. J. Res. Pak., 32 (2): 1-12.

Mekdad, A.A.A. (2015). Sugar beet productivity as affected by nitrogen fertilizer and foliar spraying with boron. Int. J. Curr. Microbiol. App. Sci., 4 (4): 181-196.

Monreala, J.A., E.T. Jiméneza, E. Remesala, R. Morillo-Velardeb, S. García-Mauriñoa and C. Echevarríaa (2007). Proline content of sugar beet storage roots: Response to water deficit and nitrogen fertilization at field conditions. Environ. and Exp. Bot., 60 (2): 257-267.

Nemeata, Alla, H.E.A. (2016). Yield and quality of sugar beet as affected by sowing date, nitrogen level and foliar spraying with calcium. J. Agric. Res. Kafr El-Sheikh Univ., 42 (1): 170-188.

Ramadan, B.S.H., H.R. Hassan and F.A. Abdou (2003). Effect of mineral and biofertilizers on photosynthetic pigments, root quality, yield components and anatomical structure of sugar beet (Beta vulgaris L.) plants grown under reclaimed soils. J. Agric. Sci. Mansoura Univ., 28 (7): 5139-5160.

Saif, L.M. (2000). Stepwise regression and path coefficient analysis for some sugar beet characters under levels of boron and nitrogen fertilization. Proc. $9^{\text {th }}$ Conf. in Agron., Minufia Univ., 1: 569-581.

Saini, K.S. and N.S. Brar (2017). Sugar beet (Beta vulgaris L.) yield response to varying planting methods, densities and depth of sowing under subtropical conditions under subtropical conditions. The Bioscan., 12 (3): 1715-1720.
Sarhan, H.M. (2012). Effect of bio and mineral fertilization on yield and quality of sugar beet. J. Plant Prod., Mansoura Univ., 3 (10): 2513-2524.

Sarhan, H.M., M.A.E. Abdou and H.M. Al-Sayed (2012). Effect of planting systems, plant density and nitrogen fertilizer levels on productivity and quality of sugar beet. J. Plant Prod., Mansoura Univ., 3 (10): $2567-$ 2580.

Seadh, S.E. (2004). Agricultural studies on sugar beet crop. Ph.D. Thesis, Fac. Agric. Mansoura Univ., Egypt.

Shaban, K.A.H., E.M. Abdel Fatah and D.A. Syed (2014). Impact of humic acid mineral nitrogen fertilization on soil chemical properties, yield and quality of sugar beet under saline soil. J. Soil Sci. and Agric. Eng., Mansoura Univ., 5 (10): 1317-1335.

Shalaby, M.T., M.B. Doma, F.A. Abd El- Latif and S.M.E. Sadik (2003). Agricultural, chemical and technological studies on sugar beet. 2- Effect on nitrogen application on yield, chemical constituents and juice quality characteristics of sugar beet. J. Agric. Sci. Mansoura Univ., 28 (3):1853-1864.

Shewate, S.R., P.V. Ghodke and A.S. Patil (2008). Effect of nitrogen levels and varieties on sugar beet growth, yield and quality. Cooperative Sugar, 39 (11): 29-33.

Snedecor, G.W. and W.G. Cochran (1980). Statistical Methods. $7^{\text {th }}$ Ed. Iowa State Univ. Press, Iowa, USA.

Zaki, M.S., E.I. El-Sarag, H.A. Maamoun and M.H. Mubarak (2018). Agronomic performance sugar beet (Beta vulgaris L.) in Egypt using inorganic, organic and biofertilizers. Egypt. J. Agron., 40 (1): 89- 103.

Zhang, J.X., L. Qiang, X. Lihua and G. Yuzhu (2009). Effects of nitrogen fertilization on fibrous root distribution and activity in high yield sugar beet. Plant Nutr. and Fertilizer Sci., 15 (4): 904-909. 
Zagazig J. Agric. Res., Vol. 47 No. (2) 2020

تأثير نظم الزراعة ومستويات السماد النيتروجيني و التسميد الحيوي على إنتاجية وجودة محصول بنجر السكر تحث ظروف الأر اضي الئروي الرملية

\author{
حازم محمود سرحان - مها محمد الزينى

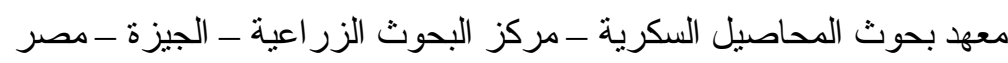

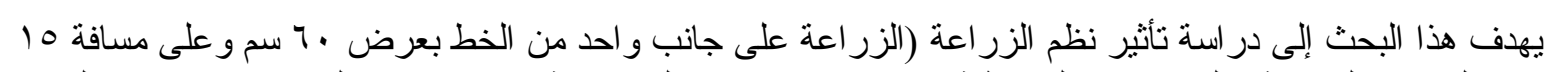

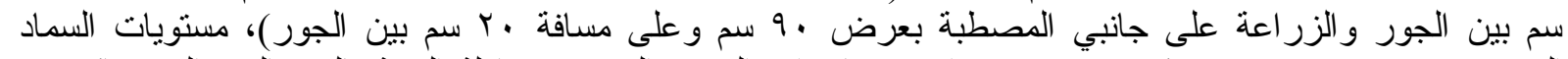

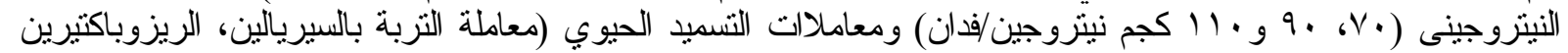

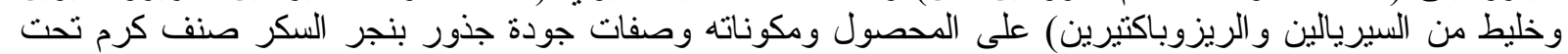

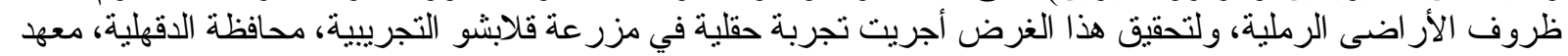

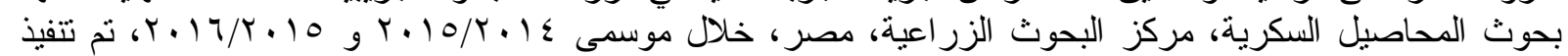

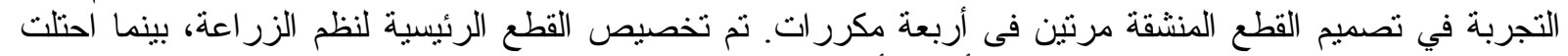

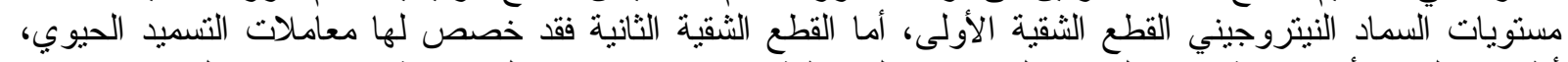

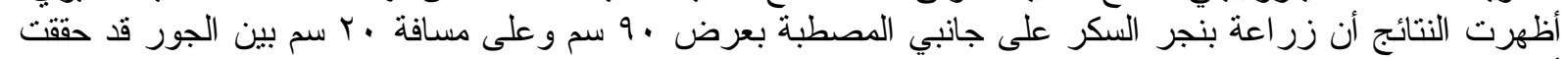

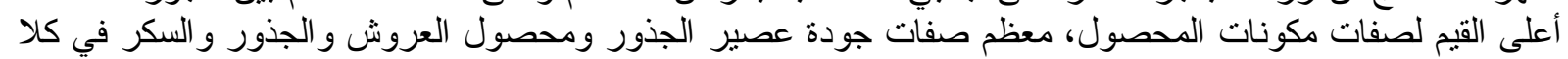

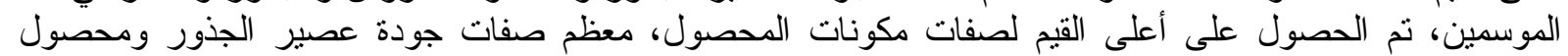

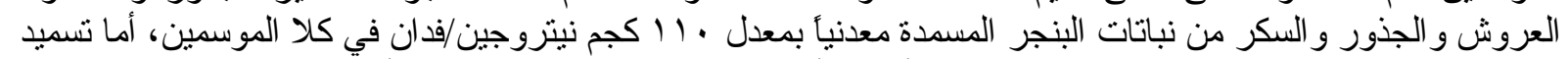

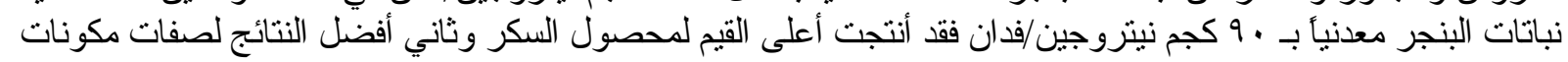

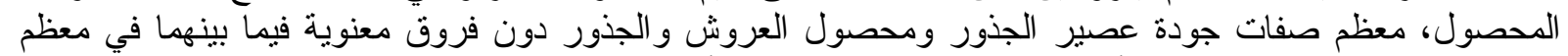

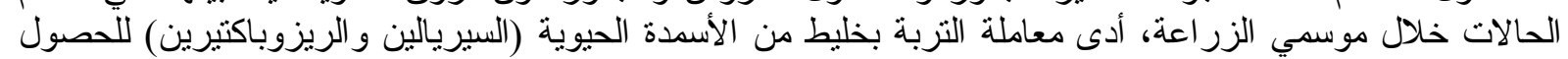

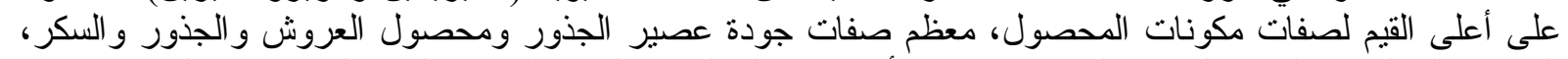

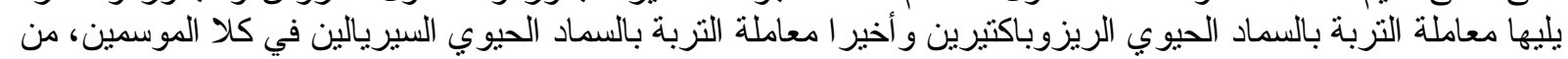

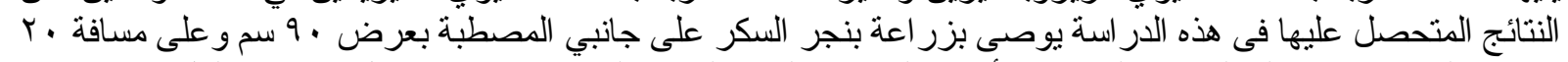

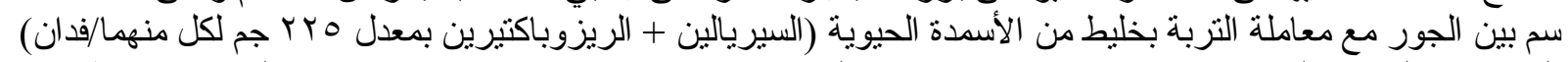

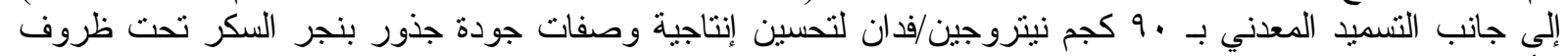
الأر اضى الرملية.

رئيس بحوث بمعهد بحوث المحاصيل السكريةـ مركز البحوث الزر اعيةـ الجيزة- مصر.

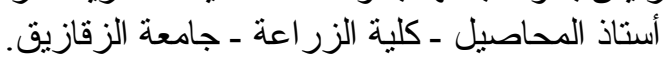

